\title{
PENGEMBANGAN ALAT PERAGA PITA PERKALIAN PADA PEMBELAJARAN MATEMATIKA DENGAN PENDEKATAN SAINTIFIK DI MI MIFTAHUL ULUM CERMENAN JOMBANG
}

\author{
Nur Kholifatur Rosyidah \\ MI Miftahul Huda Gudo Jombang \\ kholifaturrosy24@gmail.com \\ Ali Mahsun \\ Prodi PGMI Universitas Hasyim Asy'ari Tebuireng Jombang \\ alimahsun000@gmail.com
}

\begin{abstract}
Mathematics basically has basic abstract objects, which in the process of learning mathematics for children aged 7-12 years need the help of concrete objects that can be manipulated, thus helping students understand the material easily and create fun learning, especially multiplication material. So in this study, researchers developed the Multiplication Tape props for grade III students of Madrasah Ibtidaiyah. This research uses the $R \& D$ (Research and Development) design model of the Borg \& Gall development model by taking 8 stages namely, potential and problems, collecting data, product design, design validation, design revisions, product trials, product revisions, trial use. Based on product development, validation results obtained, i.e. design validation obtained $80 \%$ value in the valid category, material expert validation obtained $100 \%$ value in the highly valid category, and learning expert validation obtained $72.7 \%$ in the valid category. Whereas in large group trials based on student assessments, the score was $93.3 \%$ in the excellent category. Thus it can be concluded that the Education Multiplication Props are effectively utilized in the learning process.
\end{abstract}

Keywords: Educational Props, Multiplication Tape, Scientific Approach

\begin{abstract}
Abstraks
Matematika pada dasarnya memiliki objek dasar yang abstrak, dimana dalam proses pembelajaran matematika untuk anak usia 7-12 tahun membutuhkan bantuan benda konkrit yang dapat dimanipulasi, sehingga membantu siswa memahami materi dengan mudah dan menciptakan pembelajaran yang menyenangkan, khususnya materi perkalian. Maka dalam penelitian ini, peneliti mengembangkan alat peraga Pita Perkalian untuk siswa kelas III Madrasah Ibtidaiyah. Penelitian ini menggunakan metode $R \& D$ (Research and Development) model desain pengembangan Borg \& Gall dengan mengambil 8 tahapan yaitu, potensi dan masalah, mengumpulkan data, desain produk, validasi desain, revisi desain, uji coba produk, revisi produk, uji coba pemakaian. Berdasarkan pengembangan produk diperoleh hasil validasi, yaitu validasi desain diperoleh nilai $80 \%$ dalam kategori valid, validasi ahli materi diperoleh nilai $100 \%$ dalam kategori sangat valid, dan validasi ahli pembelajaran diperoleh nilai $72,7 \%$ dalam kategori valid. Sedangkan dalam uji coba kelompok besar berdasarkan penilaian siswa diperoleh nilai 93.3\% dalam kategori sangat baik. Dengan demikian dapat disimpulkan bahwa alat peraga edukatif Pita Perkalian efektif dimanfaatkan dalam proses pembelajran.
\end{abstract}

Kata kunci: Alat Peraga Edukatif, Pita Perkalian, Pendekatan Saintifik

Program Studi Pendidikan Guru Madrasah Ibtidaiyah

STAI Al-Azhar Menganti Gresik, Indonesia

\section{Pendahuluan}

Pendidikan merupakan suatu hal yang berperan sangat penting dalam kehidupan sehari-hari manusia, yang pada dasarnya bentuk kesadaran manusia dalam membina pribadinya sesuai nilai yang berlaku dimasyarakat, sehingga mampu menguasai berbagai ilmu pengetahuan juga keterampilan untuk menentukan jati dirinya. Peran masyarakat dalam 
dunia Pendidikan sudah terlihat sejak awal, baik dilembaga Pendidikan maupun organisasi yang berjalan dimasyarakat.

Menurut Undang-Undang SISDIKNAS no. 20 tahun 2003 pasal 1 (2006,5), adalah pendidikan adalah kesadaran dan perencanaan dalam mewujudkan proses pmbelajaran sedemikian rupa sehingga siswa dapat mengembangkan potensi dirinya secara aktif yang pada akhirnya siswa mampu mengendalikan diri, memiliki intelektual, keafektifan dalam bermasyarakat, kekuatan spiritual keagamaan, kepribadian serta akhlak mulia untuk masyarakata, bangsa juga negara. Sedangkan menurut KI Hajar Dewantoro menyatakan bahwa pendidikan adalah suatu kewajiban yang harus dilakukan dalam kehiudupan tumbuh kembangnya anak dengan maksud mengharuskan segala kekuatan kodrati pada anak supaya mereka menjadi manusia yang mampu menggapai keslamatan dan kebahagiaan setinggi mungkin (Marbun Stefanus, 2018). Maka dapat didefinisikan bahwa pendidikan adalah usaha sadar yang dilakukan oleh manusia untuk merubah tingkah laku dirinya menjadi manusia yang lebih baik malalui pelatihan-pelatihan.

Berita yang ditulis oleh Totok Amin Soefijanto (sindonews, 2018), tentang "Wajib Belajar untuk Bangsa" menyatakan bahwa dalam pendidikan formal anak diwajib belajar selama 12 tahun pada jenjang sekolah dasar hingga Sekolah Menengah Atas (SMA) atau Madarasah Aliyah (MA). Melalui tahapan pada era orde baru, tahun 1984 Wajib Belajar 6 Tahun dan pada tahun 1994 Wajar Belajar 9 Tahun. Kini pada pemerintahan Jokowi-JK mewajibkan belajar ditingkatkan menjadi 12 tahun. Dari Pendidikan formal inilah anak mendapat berbagai macam ilmu yang diberikan oleh guru, khususnya matematika.

(Sondan Arfando, 2018), menyatakan matematika merupakan ilmu yang menjadi dasar dan pelayan dari bermacam ilmu pengetahuan lainnya, karena kehadirannya sangat diperlukan dalam mendukung berdirinya ilmu lainnya, meskipun non eksak. Matematika yang dulunya disebut ilmu murni, kini sudah banyak cabang ilmu matematika yang telah dikembangkan oleh ilmuwan. Seiring dengan perkembangan teknologi yang semakin maju, cabang Matematika murni bisa diterapkan dalam berbagai ilmu pengetahuan dan teknologi. Berita yang ditulis oleh Adi Kusumo, tentang "Peran Matematika Dalam Pembangunan Bangsa” menyatakan survei yang dilakukan oleh Kementrian RISTEK, 2009 terhadap 236 responden secara keseluruhan matematikawan anggota Indonesian Mathematics Society (IndoMS) yang tersebar. Hasil menunjukkan berdasarkan bidang keahliannya, 72,9\% matematikawan Indonesia melakukan penelitian di bidang matematika terapan 35,6\%, Statistika 21,8\%, Ilmu Komputer 15,5\%, sementara sisanya melakukan penelitian di bidang 
Matematika murni yaitu Analisis (14,5\%) dan Aljabar (12,5\%). Dari hasil survei tersebut menunjukkan bahwa bidang tersebut mulai banyak digunakan untuk mempelajari dan menjawab berbagai persoalan yang terjadi dalam kehidupan sehari-hari, khususnya di bidang matematika terapan dan statistic.

Dalam dunia Pendidikan, Matematika merupakan salah satu mata pelajaran wajiib yang harus di berikan kepada siswa, mulai dari jenjang pendidikan sekolah dasar sampai jenjang perguruan tinggi. Tidak hanya berperan dalam jenjang pendidikan sekolah saja, namun matematika adalah salah satu ilmu yang memiliki peranan yang sangat penting bagi kehidupan sehari-hari. Dimana manusia dalam memenuhi kebutuhan hidupnya sehari-hari juga tidak lepas dari matematika. Matematika memberikan kontribusi yang sangat besar, mulai dari hal yang sangat sederhana sampai hal yang kompleks, mulai dari yang abstrak sampai yang konkrit untuk pemecahan masalah dalam segala bidang. Salmawaty Arif, (Tribunnews.com) menunjukkan bukti bahwa matematika juga terlibat dalam berbagai kegiatan sosial budaya masyarakat. Misalnya perdagangan selalu melakukan hitungan, pertanian memerlukan pengetahuan untuk mengetahui tentang musim dan satuan ukuran.

Namun dewasa ini banyak siswa yang tidak menyukai mata pelajaran matematika dengan berbagai alasan yang mereka perbincangkan. Dilansir oleh Anne Anggraeni Fathana (Kompas.com), sebuah studi di Amerika Serikat menyebutkan bahwa 17-30\% anak usia sekolah dasar dan menengah negara punya ketakutan tersendiri terhadap matematika. Mereka menganggap bahwa matematika adalah mata pelajaran yang menakutkan, sangat sulit dan harus dijauhi. Mereka juga mempunyai niatan untuk tidak mempelajari matematika, bahkan ada keinginan untuk menghilangkan mata pelajaran tersebut. Padahal matematika bukanlah mata pelajaran yang menakutkan dan sulit, seperti yang mereka bayangkan. Hanya saja membutuhkan kesabaran dan keuletan dalam belajar matematika.

Dampak dari hal tersebut mengakibatkan menurunnya prestasi belajar siswa dalam bidang matematika. Neneng Zubaidah, (sindonews) menyatakan data Kemendikbud melalui program Indonesia National Assesment Program (INAP) pada 2016 menunjukkan sekitar 77,13\% siswa SD di seluruh Indonesia memiliki kompetensi matematika yang sangat rendah, yakni $20,58 \%$ cukup dan hanya 2,29\% yang kategori baik. Jika hal ini terus berlanjut, maka prestasi dalam bidang matematika akan hancur. Anggapan siswa terhadap mata pelajaran matemati harsu segera diubah untuk memperbaiki prestasi dalam bidang matematika.

Matematika pada dasarnya memiliki objek dasar yang abstrak, karena berkenaan dengan fakta, prinsip, konsep abstrak yang tersusun secara penalaran. Umumnya siswa 
sekolah dasar berumur sekitar 6 atau 7 - 12 tahun. Menurut Jean Piaget (Pitajeng, 2015), anak pada umur ini berada pada periode operasi konkret, karena berpikirnya didasarkan pada manipulasi fisik objek-objek konkret. Pada peride ini umumnya siswa masih terikat dengan objek yang konkret atau cenderung berpikir konkret, rasional dan objektif dalam memahami suatu situasi. Sedangkan menurut Hudojo (Zahra Chairani, 2016), menyatakan matematika sebagai ilmu mengenal struktur dan hubungan dengan simbo-simbol yang diperlukan. Symbol-simbol tersebut penting untuk membantu memanipulasi aturan dengan operasi yang diterapkan.

Keberhasilan dalam pembelajaran matematika dipengaruhi oleh beberapa faktor, salah satunya yaitu penggunaan pendekatan saintifik dalam proses pembelajaran, dimana proses pembelajarannya terpusat pada siswa bukan lagi terpusat pada guru. Pembelajaran saintifik ini menekankan pada aktivitas siswa melalui kegiatan 5M (Mengamati, Menanya, Mencoba, Menalar, Mengkomunikasikan). Dengan pendekatan saintifik diharapkan mampu mempersipakan generasi yang berpikir kristis dan berketrampilan. Pendekatan saintifik diatur dalam Peraturan Menteri Pendidikan dan Kebudayaan Republik Indonesia Nomor 103 Tahun 2014 Tentang Pembelajaran Pada Pendidikan Dasar dan Pendidikan Menengah. Dengan pendekatan saintifik, siswa bisa belajar lebih aktif dalam pembelajaran. Siswa juga bisa belajar memecahkan masalah sendiri yang pada akhirnya akan dikomunikasikan dengan guru. Selain itu, penggunaan alat peraga juga mempengaruhi keberhasilan dalam proses pembelajaran. Dengan adanya alat peraga dapat menciptakan proses pembelajaran yang menarik dan menyenangkan.

Misalnya pada mata pelajaran matematika materi perkalian yang masih rendah ini diterapkan metode perkalian sebagai alat peraga edukatif yang dapat membantu siswa menyelesaikan perkalian lebih mudah tanpa menghafal. Peneliti berinisiatif untuk mengembangkan metode garismatika sebagai alat peraga edukatif pita perkalian, yakni alat peraga edukatif sebagai alat bantu untuk mempermudah belajar perkalian yang dirancang sesuai dengan karakteristik siswa SD/MI. Produk yang dihasilkan berupa alat peraga edukatif pita perkalian. Dinamakan pita perkalian karena pengoperasiaannya menggunakan pita yang disusun secara vertikal dan horizontal untuk menghitung titik diagonalnya sebagai hasil perkalian.

Diharapkan dengan adanya alat peraga edukatif ini dapat membantu siswa memahami materi perkalian dengan mudah tanpa menghafal khusunya di MI Miftahul Ulum Cermenan. Oleh karena itu penelitian ini dititikberatkan pada Pengembangan Alat Peraga Edukatif Pita 
Perkalian Dengan Pendekatan Saintifik Pada Pembelajaran Matematika (Materi Perkalian) di MI Miftahul Ulum Cermenan Jombang.

Berdasarkan permasalahan di atas, permasalahan yang akan dikaji terkait alat peraga edukatif pita perkalian dengan pendekatan saintifik adalah pengembangan alat peraga matematika, validasi hasil pengembangan alat peraga, dan keefektifan alat peraga sebagai salah satu solusi pembelajaran matematikan khususnya terkait dengan kompetensi dasar perkalian.

Tujuan penelitian dan pengembangan alat peraga edukatif Pita Perkalian adalah untuk menjelaskan, mengembangkan alat peraga edukatif Pita Perkalian dengan pendekatan Saintifik pada pembelajaran Matematika menurut para validator dan uji respon siswa, dan mengetahui keefektifan alat peraga edukatif Pita Perkalian dengan pendekatan Saintifik pada pembelajaran Matematika untuk kelas di MI Miftahul Ulum.

Menurut Rostina Sundayana (2016: 7) menyatakan bahwa alat peraga adalah sautu alat yang digunaakan untuk mentransfer pesan dalam pembelajaran sehingga siswa terangsang pikirannya, perasaannya, maupun perhatiannya yang dapat mendorong proses belajar mengajr. Alat peraga ini berperan untuk membantu ketidakjelasan materi yang akan disampaikan kepada siswanya sesuia dengan isi dari tujuan pembelajaran yang telah dirumuskan sebelumnya. Sedangkan Perkalian menurut fadjar shadiq (2014, Xii) merupakan operasi matematika yang mengalikan suatu angka dengan angka lainnya sehingga menghasilkan nilai tertentu yang pasti. Perkalian juga disebut sebagai bentuk penjumlahan berulang, karena bentuknya yang menjumlahkan angka yang sama sebanyak bilangan tersebut.

Jadi, alat peraga edukatif pita perkalian adalah suatu alat bantu untuk mempermudah belajar perkalian yang dirancang sesuai dengan karakteristik siswa SD/MI yang pengoperasiaannya menggunakan pita yang disusun secara vertikal dan horizontal untuk menghitung titik diagonalnya sebagai hasil perkalian.

(Rusman, 2017), menyatakan bahwa pendekatan saintifik adalah suatu pendekatan pembelajaran yang menekankan siswa pada kegiatan mengamati, menanya, mencoba, menalar, dan mengkomunikasikan, sehingga siswa secara aktif memiliki kemampuan untuk mencari, mengolah dan menggunakan pengetahuannya, dimana pembelajaran ini tidak lagi berpusat kepada guru melainkan berpusat kepada siswa, guru hanya berfungsi sebagai motivator untuk siswanya. 


\section{Metode Penelitian}

Penelitian ini menggunakan metode penelitian dan pengembangan $(R \& D)$ model pengembangan pembelajaran Borg \& Gall yang terdapat 10 tahapan pelaksanaan startegi penelitian dan pengembangan (Sugiyono, 2015), tetapi pelaksanaan strategi penelitian dan pengembangan ini hanya digunakan 8 tahapan. Hal ini dilakukan dengan pertimbangan bahwa pengembangan alat peraga edukatif yang dilakukan hanya sebatas pada uji coba pemakaian. Tahapan kesembilan (revisi produk) dan kesepuluh (produksi masal) tidak dilakukan karena keterbatasan waktu yang digunakan peneliti, sehingga dalam pengembangan ini tidak digunakan.

Prosedur dalam penelitian dan pengembangan ini adalah mencari potensi dan masalah, mengumpulkan data dan informasi dengan cara melakukan observasi ke Madrasah menggunakan data angket dan wawancata, mendesain produk yang akan dikembangkan, memvalidasi desain produk kepada ahli desain, ahli materi, dan ahli pembelajaran untuk memperoleh kritik dan saran, memperbaiki desain produk berdasarkan kritik dan saran validatr, uji coba produk untuk mengetahui kelayakan produk kepada beberapa siswa dan validator pembe;ajaran, revisi produk untuk menjadi efektif, uji coba pemakaian dengan skala besar menggunakan desain True Experimental bentuk Posttest Only Control Design dan keefektifan perlakuan dianalisis dengan uji beda memakai statistic parametrik rumus $t$-test.

Subjek dalam penelitian ini adalah siswa kelas III MI Miftahul Ulum Cermenan dengan keseluruhan siswa. Instrumen yang digunakan dalam pengumpulan data pada pengembangan ini berupa angket, yaitu Angket penilaian ahli materi, angket penilaian ahli desain, angket penilaian ahli pembelajaran/ guru Matematika kelas III, angket penilaian siswa uji coba lapangan, pedoman wawancara, dan posttes.

Jenis data yang digunakan dalam penelitian pengembangan ini adalah data kuantitatif dan data kualitatif. Data kuantitatif diperoleh dari angket pertanyaan tertutup terhadap hasil uji coba untuk mengetahui kevalidan alat peraga edukatif tersebut. Sedangkan data kualitatif diperoleh dari hasil wawancara berupa kritik, tanggapan dan saran dari validator.

Teknik yang digunakan peneliti dalam mengumpulkan data adalah observasi, wawancara, angket, tes, dokumentasi. Teknik analisis data yang digunakan adalah Analisis isi pembelajaran utnuk merumuskan tujuan pembelajaran matematika khususnya perkalian yang disesuaikan dengan Standar Kompetensi dan Kompetensi Dasar, analisis deskriptif ini digunakan untuk menemukan tingkat kelayakan, keefektifan dan kemenarikan produk, analisis hasil eksperimen (Posttest) digunakan untuk menghitung nilai rata-rata posstest dari seluruh siswa.

\section{Hasil Penelitian dan Pembahasan}

Hasil produk yang dikembangkan pada penelitian ini berupa alat peraga edukatif Pita Perkalian. Adapun deskripsi dari produk alat peraga edukatif Pita Perkalian adalah sebagai berikut: 
Bentuk fisik, Bentuk 3 Dimensi, Judul: Alat Peraga Edukatif Pita Perkalian, Materi: Perkalian, Sasaran: Siswa kelas III MI Miftahul Ulum Cermenan. Bahan dan Kegunaan:

1. Papan soal terbuat dari kayu berukuran $46 \mathrm{~cm} \times 0,5 \mathrm{~cm} \times 13,5 \mathrm{~cm}$ yang yang dilapisi stiker skotlet digunakan unntuk menuliskan soal yang akan dibahas.

2. Pita perkalian digunakan untuk menghitung hasil kali dengan cara menjumlahkan titik pertemuan 2 pita yang terbuat dari kayu balok berukuran $32,5 \mathrm{~cm}$ x $1,5 \mathrm{~cm} \times 2,5 \mathrm{~cm}$. pada masing-masing sisi terdapat 4 kawat yang disusun sejajar digunakan untuk mengaitkan pita yang berbeda warna yaitu merah, hijau, kuning, dan hitam.

3. Papan jawaban terbuat dari kayu berukuran $46 \mathrm{~cm} \times 0,5 \mathrm{~cm} \times 13,5 \mathrm{~cm}$ yang dilapisi stiker skotlet digunakan untuk menuliskan jawaban dari soal dibahas.

4. Penyangga terbuat dari kayu balok berukuran $15 \mathrm{~cm} \times 2,5 \mathrm{~cm} \times 1,5 \mathrm{~cm}$.

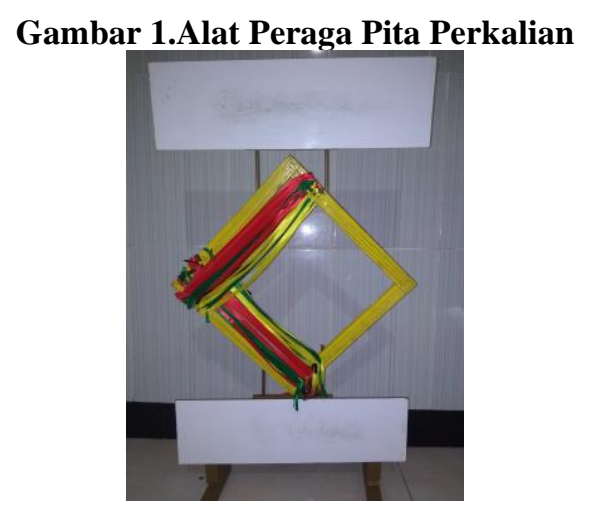

Sebelum mendesain produk alat peraga edukatif Pita Perkalian, peneliti menemukan potensi dan masalah dengan melakukan observasi terlebih dahulu di MI Miftahul Ulum Cermenan. Berdasarkan observasi yang dilakukan, peneliti menemukan masalah kurang semangatnya siswa dalam belajar matematika materi yang akan mengakibatkan menurunnya mutu pembelajaran. Selain itu, belum digunakannya alat peraga edukatif pada pembelajaran Matematika pada materi perkalian dan pembelajaran hanya mengacu pada buku panduan siswa yang menyebabkan proses pembelajaran kurang maksimal.

Selanjutnya, peneliti mengumpulkan informasi dengan melakukan wawancara kepada guru matematika di MI Miftahul Ulum Cermenandan dinyatakan bahwa dalam pembelajaran matematika khususnya materi perkalian siswa masih kesulitan dalam memahami konsep perkalian. Disamping itu, kurangnya minat siswa dalam mempelajari matematika materi perkalian dengan berbagai alasan.

Berdasarkan permasalahan yang terjadi, penulis mempunyai inisiatif untuk mengembangkan alat peraga matematika materi perkalian, sehingga memudahkan siswa dalam belajar memahami perkalian. Setelah mendesain produk Pita Perkalian, kemudian peneliti melakukan validasi kepada tiga ahli, yaitu ahli desain, ahli materi, dan ahli pembelajaran. Validasi ahli desain dilakukan dua kali, pertama memperoleh nilai 40 dengan presentase $80 \%$ yang dinyatakan "valid" dalam kualifikasi 
pencapaian dan tidak perlu revisi. Kedua, memperoleh nilai 40 dengan presentase $80 \%$ yang dinyatakan "valid" dalam kualifikasi pencapaian dan tidak perlu revisi.

Setelah dilakukan validasi desain, kemudian dilakukan validasi ahli materi matematika secara dua tahap, tahap I diperoleh nilai 44 denga presentase 98\% yang dinyatakan "sangat valid" dalam kualifikais pencapaian. Setelah direvisi sesuai saran dan komentar validator, kemudian dilakukan validasi tahap II yayng dipeorleh nilai 45 dengan presentase 100\% yang dinyatakan "sangat valid" dalam kualifikasi pencapaina. Kemudian validasi ahli pembelajaran yang dilakukan oleh guru matematika kelas III MI Miftahul Ulum Cermenan diperoleh nilai 40 dengan presentase $72.7 \%$ yang dinyatakan "valid" dalam kualifikasi pencapaian dan tidak perlu revisi.

Setelah alat peraga edukatif Pita Perkalian mendapat rekomendasi layak untuk dikembangkan, kemudian dilakukan uji coba lapangan. uji coab dilakukan sebanyak 2 kali, yaitu Ujincoba kelompok kecil dilakukan sebanyak 12 siswa kelas III MI Miftahhul Ulum Cermenan yang dipilih secara random dan diperoleh skor 714 denagn presentase $91.5 \%$ yang dinyatakan "sangat valid" dalam kualifiksai pencapaian. Selanjutnya dilakukan uji coba kelompok besar sebanyak 20 siswa kelas III MI Miftahhul Ulum Cermenan dengan diperoleh skor 1214 dengan presentase 93.3\% yang dinyatakan "sangat valid" dalam kualifikasi pencapaian.

Berdasarkan perhitungan hasil validasi alat peraga edukatif Pita Perkalian oleh empat validator ahli menunjukkan bahwa alat peraga edukatif Pita Perkalian dikategorikan "Baik". Pengembangan alat peraga ini dilakukan melalui 8 tahapan yaitu, potensi dan masalah, mengumpulkan data, desain produk, validasi desain, revisi desain, uji coba produk, revisi produk, uji coba pemakaian.

Berdasarkan hasil penelitian didapatkan produk yang berhasil dikembangkan pada penelitian ini berupa alat peraga edukatif Pita Perkalian. Alat peraga ini berbentuk 3 dimensi dan digunakan untuk materi perkalian terbuat dari kayu berukuran $46 \mathrm{~cm} \times 0,5 \mathrm{~cm}$ x 13,5 $\mathrm{cm}$ yang yang dilapisi stiker skotlet digunakan unntuk menuliskan soal yang akan dibahas. Pita perkalian ini digunakan untuk menghitung hasil kali dengan cara menjumlahkan titik pertemuan 2 pita yang terbuat dari kayu balok berukuran $32,5 \mathrm{~cm} \times 1,5 \mathrm{~cm} \times 2,5 \mathrm{~cm}$. pada masing-masing sisi terdapat 4 kawat yang disusun sejajar digunakan untuk mengaitkan pita yang berbeda warna yaitu merah, hijau, kuning, dan hitam. Adapun papan jawaban terbuat dari kayu berukuran $46 \mathrm{~cm}$ x $0,5 \mathrm{~cm} \times 13,5 \mathrm{~cm}$ yang dilapisi stiker skotlet digunakan untuk menuliskan jawaban dari soal dibahas. Penyangga terbuat dari kayu balok berukuran $15 \mathrm{~cm} \times 2,5 \mathrm{~cm} \times 1,5 \mathrm{~cm}$. Pengembangan alat peraga edukatif ini didasari oleh permasalahan yang ditemukan di MI Miftahul Ulum Cermenan yang menunjukkan bahwa ketersedian alat peraga perkalian yang masih terbatas, dan juga hasil dari wawancara kepada guru mata pelajaran matematika bahwa mereka masih kesulitan dalam pembelajaran matematika materi perkalian. Dengan demikian, peneliti mempunyai inisiatif untuk mengembangakan alat peraga matematika materi perkalian yang dapat membantu siswa untuk mempermudah berhitung perkalian. Alat peraga edukatif 
Pita Perkaliain ini telah memenuhi salah satu kompetensi dasar (4.3 melakukan perkalian yang hasilnya bilangan tiga angka) dan indikator pembelajaran matematika (4.3.1 memahami pengertian perkalian, 4.3.2 melakukan perkalian yang mengahsilkan bilangan tiga angka, dan 4.3.3 menyelesaikan soal cerita).

Alat peraga edukatif Pita Perkalian yang telah dkembangkan kemudian diuji kelayakannya kepada validator ahli, yaitu ahli desain, ahli materi, dan ahli pembelajaran dengan menggunakan angket penilaian skala likert untuk memperoleh data kuantitatif, sedangkan data kualitatif diperoleh dari komentar dan saran dari validator. Validasi alat peraga divalidasi ahli desain alat peraga dengan memperoleh nilai 40 dengan presentase $80 \%$ yang dinyatakan "valid" dalam kualifikasi pencapaian dan tidak perlu revisi. Kemudian validasi ahli materi dilakuakn oleh ahli materi matematika sebanyak 2 tahap. Validasi tahap I diperoleh nilai 44 denga presentase 98\% yang dinyatakan "sangat valid" dalam kualifikasi pencapaian. Sedangkan validasi tahap II diperoleh nilai 45 dengan presentase 100\% yang dinyatakan "sangat valid" dalam kualifikasi pencapaian. Kemudian validasi ahli pembelajaran dilakukan oleh ahli pembelajaran matematika dengan diperoleh nilai 40 dengan presentase $72.7 \%$ yang dinyatakan "valid" dalam kualifikasi pencapaian. Berdasarkan hasil validasi dari ahli desain media dan ahli materi pembelajaran matematika, maka alat peraga edukatif Pita Perkalian mendapat rekomendasi layak untuk dikembangkan, kemudian dilakukan uji coba lapangan.

Uji coba dilakukan sebanyak 2 kali, yaitu uji coba kelompok kecil dan uji coba kelompok besar. Uji coba kelompok kecil memperoleh skor 714 denagn presentase $91.5 \%$ yang dinyatakan "sangat valid" dalam kualifiksai pencapaian. Selanjutnya uji coba kelompok besar memperoleh skor 1214 dengan presentase $93.3 \%$ yang dinyatakan "sangat valid" dalam kualifikasi pencapaian. Berdasarkan perhitungan hasil validasi alat peraga edukatif Pita Perkalian oleh empat validator ahli menunjukkan bahwa alat peraga edukatif Pita Perkalian dikategorikan "Baik".

Tujuan dari pengembangan alat peraga edukatif Pita Perkalian adalah untuk meningkatkan kualitas pembelajaran, dimana alat peraga merupakan sarana yang dapat dimanipulasi dan digunakan untuk mempengaruhi pikiran serta perhatian dan sikap siswa dalam pembelajaran, sehingga mempermudah terjadinya proses pembelajaran dan meningkatnya hasil belajar siswa sesuai dengan tujuan pembelajaran yang diingin dicapai. Pengukuran tingkat keefektifan atau kevalidan alat peraga edukatif Pita Perkalian dilakukan melalui tes antara kelompok kontrol dengan kelompok eksperimen dengan desain True Experimental bentuk posttest only control design. Posttest. Hasil posttest menunjukkan bahwa terdapat perbedaan antara kelompok control dan kelompok eksperimen yang menggunakan alat peraga edukatif Pita Perkalian dalam pembelajaran dengan nilai rata-rata 87.5 lebih tinggi dari kelompok kontrol yang memperoleh nilai rata-rata 48.5.

Berdasarkan data hasil uji posttest menunjukkan bahwa nilai rata-rata posttest kelompok kontrol adalah 48.5, sedangkan nilai rata-rata posttest kelompok eksperimen adalah 87.5. Hal ini menunjukkan bahwa nilai posttest kelompok eksperimen lebih bagus daripada nilai posttest kelompok control. Dengan demikian dapat disimpulkan bahwa ada keefektifan alat peraga edukatif Pita Perkalian terhadap hasil belajar siswa. Selain itu berdasarkan pengujian dengan SPSS menggunakan 
uji T-test dan diperoleh nilai sig. (2-tailed) sebesar 0,000. Hal ini berarti nilai sig $(0,000)<\alpha$, maka $\mathrm{H}_{0}$ ditolak dan $\mathrm{H}_{\mathrm{A}}$ diterima, sehingga dapat disimpulkan bahwa ada perbedaan hasil posttest kelmpok control dengan hasil posttest kelompok eksperimen yang menggunakan alat peraga edukatif Pita Perkalian. Berdasarkan adanya kenaikan nilai rata-rata posttest siswa kelompok kontrol dan kelompok eksperimen, dapat disimpulkan bahwa penggunaan alat peraga edukatif Pita Perkalian efektif digunakan untuk meningkatkan hasil belajar siswa pada pemeblajaran matematika materi perkalian.

\section{Simpulan}

Proses pengembangan alat peraga edukatif Pita Perkalian diawali dengan menemukan potensi dan masalah dengan cara observasi ke Madrasah. Kemudian mengumpulkan informasi dengan melakukan wawancara kepada guru yang bersangkutan. Selanjutnya mendesain produk yang akan dikembangkan, melakukan validasi kepada ahli desain, ahli materi, dan ahli pembelajaran untuk memperoleh kritik dan saran, memperbaiki desain produk berdasarkan kritik dan saran validator, uji coba produk untuk mengetahui kelayakan produk kepada beberapa siswa dan validator pembelajaran, revisi produk untuk menjadi efektif, uji coba pemakaian.

Hasil validasi alat peraga edukatif Pita Perkalian dengan pendekatan saintifik menurut validator ahli desain pertama mempeorleh nilai $80 \%$ yang dinyatakan "valid" dalam kualifikasi pencapaian dan tidak perlu revisi. Kedua, memperoleh nilai $80 \%$ yang dinyatakan "valid" dalam kualifikasi pencapaian dan tidak perlu revisi. Validasi ahli maeri matematika tahap I memperoleh nilai 98\% yang dinyatakan "sangat valid" dalam kualifikais pencapaian. Setelah direvisi sesuai saran dan komentar validator, kemudian dilakukan validasi tahap II yayng dipeorleh $100 \%$ yang dinyatakan "sangat valid" dalam kualifikasi pencapaian. Kemudian validasi pembelajaran yang dilakukan oleh guru matematika MI Mifathul ulum memperoleh nilai 72.7\% yang dinyatakan "valid" dalam kualifikasi pencapaian dan tidak perlu revisi. Sedangkan uji coba lapangan kelompok kecil diperoleh nilai $91.5 \%$ dan uji coba kelompok besar dipeorleh nilai 93.3\% yang dinyatakan "sangat valid" dalam kualifiksai pencapaian.

\section{Daftar Pustaka}

Arfando, Mohammad Sondan. (2018). Misteri angka Di Balik Al-Qur'an. Jakarta: Cerdas Pustaka Publisher.

Arif, Salmawaty. "Khazanah Matematika”.. Diakses tanggal 14 November 2018.

Chairani, Zahra. (2016). Metakognisi Siswa dalam Pemecahan Masalah Matematika. Yogyakarta: Deepublish.

Fathana, Anne Anggraeni. "Matematika Tak Sekadar Urusan Berhitung". . Diakses tanggal 14 November 2018.

Kusumo, F. Adi. "Peran Matematika Dalam Pembangunan Bangsa". . Diakses pada tanggal 15 November 2018. 
ZAHRA: Research And Tought Elmentary School Of Islam Journal Vol. (1) (1), (Agustus)(2020), (Halaman)(15-25)| Ilmu.

Pitajeng. (2015). Pembelajaran Matematika Yang Menyenangkan. Yogyakarta: Graha

Rusman. (2017). Belajar \& Pembelajaran: Berorientasi Standar Proses Pendidikan. Cet. 1;Jakarta: Kencana.

Soefijanto, Totok Amin. "Wajib Belajar untuki Bangsa". . Diakses tanggal 14 oktober 2018. Indonesia.

Stefanus, M. Marbun. (2018). Psikologi Pendidika. Ponorogo: Uwais Inspirasi

Sugiyono. (2015). Metode Penelitian Pendidikan: Pendekatan Kuantitatif, Kualitatif, dan $R \& D$. Cet. 21. Bandung: Alfabeta.

Sundayana, H. Rostina. (2016). Media dan Alat Peraga Dalam Pembelajaran Matematika. Bandung: Alfabeta, 2016.

Depdiknas. (2007). Undang-undang Nomor 20 Tahun 2003 tentang Sistem Pendidikan Nasional \& Undang-undang No.14 th 2005 tentang Guru \& dosen. Jakarta: Visimedia.

Zubaidah, Neneng. "Indonesia Gawat Darurat Matematika”. Diakses pada tanggal 16 November 2018. 